\title{
ПЕРСПЕКТИВЫ ДАЛЬНЕЙШЕГО РАЗВИТИЯ ПОИСКОВО-РАЗВЕДОЧНЫХ РАБОТ НА НЕФТЬ И ГАЗ ПО РЕЗУЛЬТАТАМ РЕГИОНАЛЬНЫХ РАБОТ В ЮЖНОЙ ЧАСТИ ПРЕДУРАЛЬСКОГО КРАЕВОГО ПТОГИБА.
}

Кондрашова Н.В., Стома Е.В., Благосиыслова Л.А. (ОАО "Оренбургская геофизическая экспеоияия")

В южной части Предуральского прогиба (ПКП) по фундаменту и осадочному чехлу выделяется Бельская впадина меридионального простиранця, в пределах которой и расположен рассматриваемый нами район.

На примере отработанного МОГТ-2Д ШП 2006 году субмеридионального профиля 40 в докладе рассмотрены основные результаты работ.

Профиль протрассирован от границы с Казахстаном, пересекает северо-восточный борт Прикаспийской синеклизы, юго-восточный наиболее погруженный участок Соль-Илецкого свода и далее пересекая западный борт ПКП трассируется вдоль западной зоны его депрессионной части, через ранее выявленные Староключевское, Теректинское, Рождественское месторождения и до границы с Башкирией.

В ПКП ранее проведен большой объем геолого-разведочных работ. Были выделены перспективные зоны и объекты, на которых глубоким бурением открыт ряд месторождений. Однако все открытые месторождения небольшие по размерам и запасам.

При опоисковании бурением целого ряда объектов центральной части ПКП, его восточного борта и зоны передовых складок положительные результаты не получены. В целом эффективность ранее проведенных ГРР в ПКП - низкая. Причина очень сложные сейсмогеологические условия, связанные с развитием соляно-купольной тектоники, большими глубинами залегания целевых горизонтов, резкими изменениями литолого-фациального состава и толщин стратитрафических подразделений, что наглядно демонстрирует профиль 400507.

Вместе с тем по заключениям специалистов (Яхимович, Политыкина и др.), проводивших обобщение и анализ геолого-геофизической информации накопленной в ПКП, перспективы нефтегазоностности, особенно в Оренбургской его части оцениваются очень высоко. Но эффективность освоения этих земель напрямую зависит от обоснования моделей поисковых объектов. Последние и являются целью проведения на новом технико- методическом уровне ОАО ОГЭ региональных сейсморазведочных исследований.

В результате интерпретации временного разреза профиля получены уточненные данные 0 строении ПКП и намечены перспективные участки для дальнейшего проведения ГРР.

На разрезе выделено семь сейсмостратиграфических комплексов (ССК) и прослежены отражающие горизонты, сопоставляемые с поверхностью фундамента, додевонского комплекса отложений, а также отложениями девона, карбона и перми.

В отдельных интервалах профиля уверенно фиксируется несогласие и размыв рифейских отложений.

Ловуики в отложениях венда, ордовика, силура возможны как антиклинальғые, так и неанти-

клинальные, образовавшиеся в результате выклинивания отложений под нижнедевонским региональном несогласием..

CCK-2,3,4 включают терригеннокарбонатные отложения нижнедевонскобашкирского возрастов. По этим комптексам зафиксирована ранее установленная сейсморазведкой высокоампіитудная тектоническая ступень (флексура), пересекаюшая чентральную часть Предуральского краевого прогиба в северо-восточном направлении.

На профиле видно, если визейскобашкирский (Б-У) комплекс (ССК-4) характеризуется незначительным изменением толщины, то толщина нижележащего комплекса нижнедевонсконижнефранского (О-Д $\left.\left(Д_{2}\right)\right)$ имеет минимальное значение в центральной части профиля, в пределах предполагаемого Акбулакского выступа фундамента, испытавшего инверсионное воздымание в послеэйфельское время. В девонский период здесь процессы денудации преобладали над процессами седиментации. В этой связи наиболее достоверные нефтегазоперспективы в районе профиля 40 связаны с отложениями среднего карбона, нижнего, среднего девона. В западной части ПКП несомненны перспективы башкирского яруса, в связи с наличием покрышки (терригенно-карбонатных отложений верейского горизонта). Перспективы других отложений возможны при наличии покрышек.

Впервые на временном разрезе профиля 40 зафиксировано положение визейско-башкирского и нижнепермского бортовых уступов Прикаспийской впадины.

Следует отметить, что результаты интерпретации временного разреза удовлетворительно соответствуют данным переинтерпретации материалов магниторазведки и новым данным гравиразведки. Находят подтверждение на временном разрезе профиля 40 как выделенные этими методами выступы фундамента, так и перспективные участки, соответствующие выделенным сейсморазведкой структурам и предполагаемым перспективным участкам.

Таким образом, в результате проведенных сейсморазведочных и гравиметрических исследований на региональном пр. 40 , представлена уточненная геологическая модель западной части ПКП. Onределены наиболее перспективные зоны для дальнейшего продолжения в этой части Предуральского краевого прогиба геологоразведочных работ. 